\title{
Dysfunctional Labor
}

National Cancer Institute

\section{Source}

National Cancer Institute. Dysfunctional Labor. NCI Thesaurus. Code C113492.

Uterine contractions (less than 3 in 10 minutes or inadequate strength) that do not result in prog ressive cervical dilation. 